\title{
Prospective primary school teachers' change in attitudes and anxiety profiles during their preparation program
}

\author{
İsmail Sarikaya ${ }^{1}$ and Yavuz Sökmen ${ }^{2}$ \\ ${ }^{1}$ Bayburt University, Education Faculty, Department of Primary Education, Turkey (ORCID: 0000-0002-4870-8345) \\ ${ }^{2}$ Atatürk University, Kazım Karabekir Education Faculty, Department of Primary Education, Turkey (ORCID: 0000-0001-7723-0144)
}

\begin{abstract}
The sensory characteristics of teachers and prospective teachers directly affect them and their teaching activities. It is important to examine in detail how the attitude and anxiety levels of prospective primary teachers towards the teaching profession change throughout the years they receive education. This study aimed to cross-sectionally and longitudinally examine whether the attitude and anxiety levels of prospective primary school teachers towards the teaching profession changed throughout their undergraduate education and determine the factors/experiences triggering this change in accordance with the qualitative data obtained. A cross-sectional study was carried out with the participation of 1085 prospective teachers. For the longitudinal study, quantitative and qualitative data were collected together from 57 prospective teachers over a period of four years. Attitude scale regarding teaching and occupational anxiety scale for prospective teachers were used for data collection. The results of both the cross-sectional and longitudinal studies showed that the attitude scores of the participants did not change in accordance with the grade level. However, it was determined that the anxiety scores of the participants decreased as the grade level increased. The results revealed that this change is statistically significant. The qualitative results revealed that internship practices and direct experiences had a great influence on this change.
\end{abstract}

Keywords: Anxiety; Attitude; Prospective primary school teachers; Teacher education; Teaching profession

Article History: Submitted 27 August 2021; Revised 7 December 2021; Published online 8 February 2022

\section{Introduction}

The attitudes and anxiety levels of prospective teachers towards the teaching profession are crucial in terms of achieving the desired outcomes from the education system. This is because it has been reported that the attitudes of prospective primary school teachers towards the profession are important variables when they begin their career (Serin et al., 2015). The quality of the education prospective teachers receive is significant in this particular issue. Teachers in Turkey receive an undergraduate education in the education faculties of universities (Durdukoca \& Atalay, 2019). Within this framework, it has been observed that undergraduate programs have been updated in

Address of Corresponding Author

İsmail Sarikaya, PhD, Bayburt University, Education Faculty, Bâbertî Campus, Tuzcuzade Neighborhood, Demirözü Street, Erzincan Road Over 2.7 km, Bayburt, Turkey.

$\triangle$ ismailsarikaya@bayburt.edu.tr

How to cite: Sarikaya, İ. \& Sökmen, Y. (2022). Prospective primary school teachers' change in attitudes and anxiety profiles during their preparation program. Journal of Pedagogical Research, 6(1), 18-39. https://dx.doi.org/10.33902/JPR.2022175399 
different years $(1996,2006,2009,2018)$ since the teacher training responsibility was transferred to universities in Turkey. When the 2018-2019 academic year curriculum for primary school teacher training programs was analysed, it was observed that it consisted of 35\% Vocational Knowledge courses (sociology of education, educational psychology, computer and instructional technologies, teaching principles and methods etc.) 19\% General Knowledge courses (information technologies, health and nutrition, media literacy etc.) and 46\% Field Education courses (basic mathematics in primary education, basic science in primary education, teaching literacy, drama, teaching English as a foreign language etc.).

It was determined that the school experience and teaching practice courses, which are applied courses, were given in the first and fourth grade until 2006, and place in the third and fourth grade after 2006 (Saka, 2019). In addition, it was observed that the school experience course, which provides prospective teachers the opportunity to practice, was not included in the updated curriculum for the undergraduate primary school teaching program of the 2018-2019 academic year. Participants of the present study took school experience courses in the spring term of their 3rd grade and teaching practice courses in both terms of their 4th grade. Within the scope of the school experience course, prospective teachers were expected to make observations and report on different topics such as classroom management, student-teacher interaction, teacher-parent interaction, teacher-colleague interaction, teaching activities and practices for special students. These reports were examined in detail every week and the prospective teachers were given feedback. In the teaching practice courses, in addition to observations, the prospective teachers were given the opportunity to live direct experiences. Within the scope of the teaching practice courses the prospective teachers completed the necessary preparations and taught classes under the supervision of their advisor. During this process the advisor were able to intervene directly where necessary. Furthermore, the prospective teachers were monitored at least four times with the participation of a field expert assigned from the university and informed about their performance throughout the process. The practicing processes of prospective teachers provide the opportunity to transfer various achievements (Saka, 2019). In addition, the previous educational experiences of prospective teachers considerably affect their teaching experiences (Conderman et al., 2005). School experience course provide a real class environment for prospective teachers to develop a positive attitude towards the teaching profession (Kirçiçek \& Yüksel, 2019). It can be said that teaching practices and school experience courses are crucial as they provide prospective teachers experience before they embark on their profession (Ergişi, 2019). It has been considered that such courses can affect the attitudes and anxiety of prospective teachers towards the teaching profession. Teachers and teacher candidates' occupational anxiety has been the subject of several studies that have been undertaken with a variety of variables. Several researches have been conducted about the occupational anxiety of teacher candidates (Doğan \& Çoban, 2009; Dursun \& Karagün, 2012; Ferguson et al., 2012; Gresham, 2007; Taşğın, 2006), as well as the occupational anxiety of teacher candidates (Beilock et al., 2010; Frenzel et al., 2016; Ghaith \& Shaaban, 2009).

\section{Theoretical Framework and Literature Review}

\subsection{The Attitude towards the Teaching Profession}

Attitude is based on Gordon Allport's theories, especially in social psychology field studies (Andronache et al., 2014). One of the most important factors that affects the success and effectiveness of teachers is their attitude towards the profession (Güneyli \& Aslan, 2009). It has been established that one of the most important elements of the education system is teachers (Aslan \& Sağlam, 2018; Kircicek \& Yuksel, 2019). In addition, the attitudes of teachers towards their profession has also been reported to be one of the most important factors affecting the professional success (Polat, 2013). Accordingly, it can be said that the attitudes of teachers towards their professions is an important variable in ensuring the desired educational outcomes. Within this scope, many studies have been carried out with various variables to examine the attitudes of prospective teachers towards the teaching profession. It was examined according to variables such 
as gender (eg. Bilgin \& Aykac, 2016; Fadlelmula, 2013; Kesen \& Polat, 2014; Taşdemir, 2014; Uyanık, 2017), university preferences (eg. Bozdoğan et al., 2007; Çapa \& Çil, 2000; Özder et al., 2010; Tok, 2012), socio-economic level (eg. Bozdoğan et al., 2007; Eret-Orhan \& Ok, 2014; Taşdemir, 2014), grade level (eg. Başbay et al., 2009; Bilgin \& Aykac, 2016; Fadlelmula, 2013; Uyanık, 2017), department graduated (eg. Aksoy, 2010; Bilgin \& Aykac, 2016; Tezci \& Terzi, 2010; Uyanık, 2017), and professional experience (eg. Başbay et al., 2009; Eret-Orhan \& Ok, 2014; Nalçacı \& Sökmen, 2016). However, it can be seen that the study findings are often contradictory. For example, Fadlelmula (2013) reports that attitudes towards the teaching profession differ significantly according to grade level. On the other hand, Uyanik (2017) reveals that attitudes do not differ significantly according to grade level. This situation also reveals the importance of the current research. As a matter of fact, almost all of the studies in the literature are cross-sectional studies. With this study, the change in attitudes has been examined by considering both cross-sectional, longitudinal and qualitative data. This may clarify the discussions. A map of the most frequently used keywords in studies examining the attitudes of teachers towards their profession created using the Web of Science database and VOSviewer software is given in Figure 1.

Figure 1

The Most Frequently Used Keywords in Studies Conducted on the Attitudes of Teachers towards the Teaching Profession

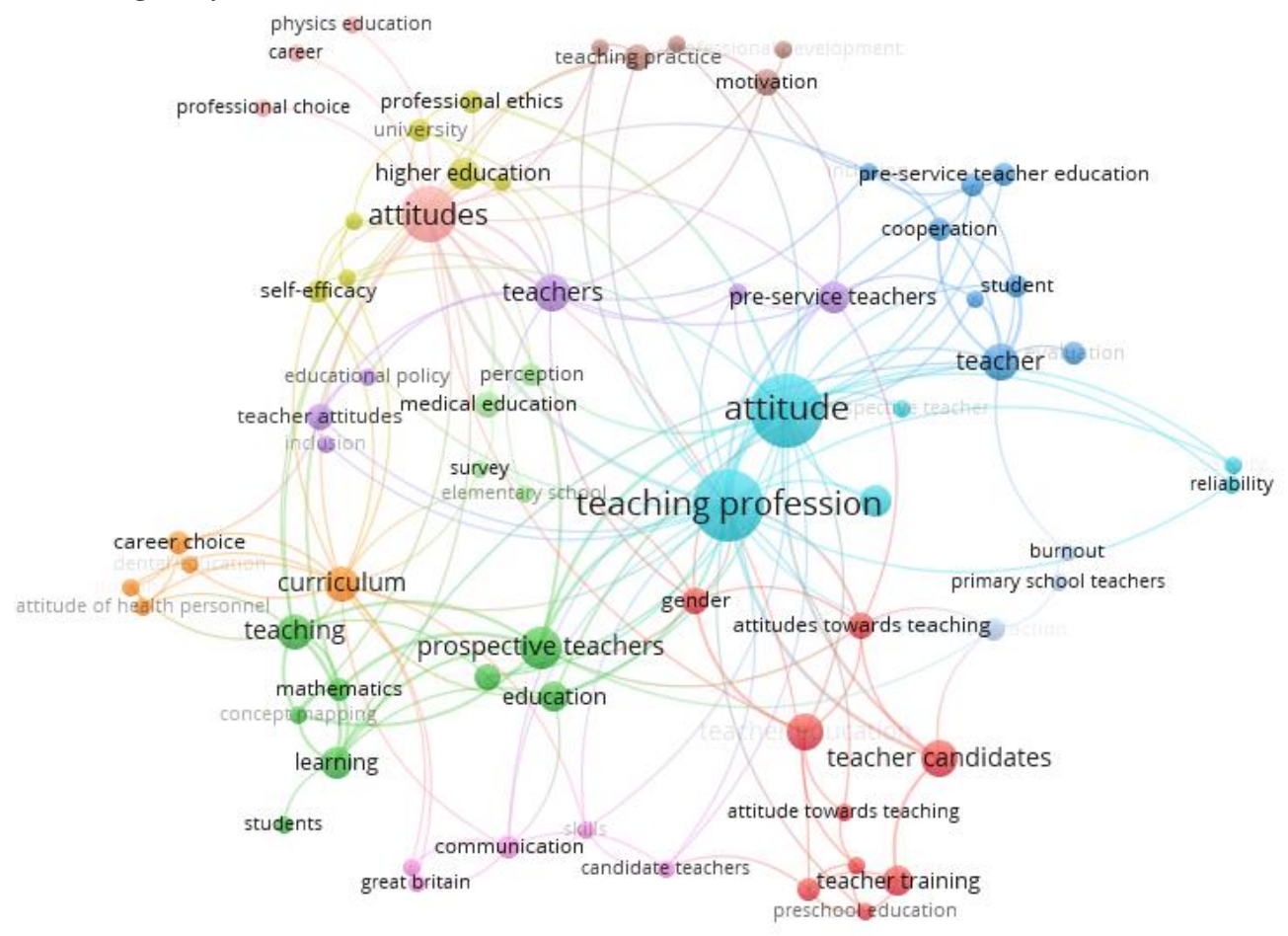

As illustrated in Figure 1 , attitude $(\mathrm{f}=30)$, teaching profession $(\mathrm{f}=29)$, attitudes $(\mathrm{f}=18)$, prospective teachers $(\mathrm{f}=10)$, teacher $(\mathrm{s})(\mathrm{f}=8)$, teacher candidates $(\mathrm{f}=8)$, teacher education $(\mathrm{f}=8)$ and curriculum $(\mathrm{f}=7)$ were the most frequently used keywords in the relevant studies. Keywords provide clues about the field of studies in the literature. It was determined that the studies mainly focused on prospective teachers and the teacher training process. Furthermore, while utilizing the VOSviewer software to evaluate publications from the Web of Science database, it was discovered that attitudes toward the teaching profession were the most investigated in Turkey. A variety of factors are thought to have played a role in the creation of this circumstance. In Turkey, the choice of teaching profession is made at the graduate level and through a centralized test. Students' placements are chosen by combining their centralized placement test scores with their secondary education grade point averages. Various studies have reported that some of the students who choose the teaching profession only do so because their scores are adequate. In addition, some 
studies have emphasized that family and immediate circles are influential in the choice of profession (Abişeva, 1997; Ensari \& Hazal, 2017). The fact that prospective teachers who choose the teaching profession based on their scores or as a result of the influence of their immediate circles have low attitudes towards the profession can be considered normal as they have not willingly chosen the teaching profession. Accordingly, the attitudes of such prospective teachers can change in the later stages of their education. This is a situation that has caught the attention of researchers and can explain the reason for intensive studies conducted on the attitudes towards the teaching profession in Turkey and other countries where similar practices are carried out. Unlike the other studies in the literature, the present study aimed to determine the attitudes and anxieties of students by evaluating them within the framework of cross-sectional, longitudinal and qualitative data.

\subsection{Anxiety towards the Teaching Profession}

In the general sense, anxiety can be defined as an inherent emotional reaction to environmental and psychological events (Spielberg \& Vagg, 1995). It can also be defined as a weakening emotion (Zeidner, 2007). Prospective teachers can be worried up to a certain point when they are being observed or evaluated and as a result, prospective teachers graduate with a high level of anxiety and are more likely to convey these anxieties to their students than others (Daniels et al., 2011). Moreover, the anxiety prospective teachers experience negatively affects them and their teaching activities (Silvernail \& Costello, 1983).

There are various studies in the literature that have been carried out on the anxiety levels of prospective teachers with different variables such as gender (eg. Durdukoca \& Atalay, 2019; Hollingsworth \& Knight-McKenna, 2018), age (eg. Bozdam, 2008; Gresham, 2007), grade level (eg. Bekdemir, 2010; Gümrükçü Bilgili, 2016), university preferences (eg. Hollingsworth \& KnightMcKenna, 2018; Yıldırım, 2011), socio-economic level (eg. Malinsky et al., 2006; Pasaribu \& Harendita, 2018), department graduated (eg. Bozdam, 2008; Durdukoca \& Atalay, 2019), and professional experience (eg. Harper \& Daane, 1998). It is noteworthy that contradictory findings are reported in studies examining anxiety levels as well as in studies examining attitudes towards the teaching profession. This may be due to the nature of the social sciences (such as the different individual characteristics of the participants). However, it is clear that there is a need for longitudinal studies that have been examined in depth with qualitative data in the literature. In this context, it can be stated that the study is important and will contribute to the literature. In addition, the most frequently used keywords were also examined in order to determine the existing trend in the literature. A map of the most frequently used keywords in studies conducted on the anxiety levels of prospective teachers is presented in Figure 2. Furthermore, studies addressing both the attitude and anxiety levels of prospective teachers towards the teaching profession can be found (Akgün \& Özgür, 2014; Doğan \& Çoban, 2009; Serin et al., 2015).

When Figure 2 was examined, it was observed that studies conducted on the anxiety level of prospective teachers tackled different issues than those that focused on attitudes. It can be seen that the most frequently used keywords were anxiety $(\mathrm{f}=43)$, motivation $(\mathrm{f}=19)$, self-efficacy ( $\mathrm{f}=17)$, teacher education $(\mathrm{f}=16)$, teachers $(\mathrm{f}=14)$, higher education $(\mathrm{f}=13)$, and mathematics anxiety $(\mathrm{f}=13)$. In addition, it can be stated that anxiety studies were carried out in a wider range compared to attitude studies. It was reported that the anxiety of prospective teachers regarding the Public Personnel Selection Examination, interviews, assignments and employment increased considerably in the senior year in Turkey (Atmaca, 2013). As a result of the $4+4+4$ system (The duration of education in primary school has been reduced from 5 years to 4 years), the number of primary school surplus teachers has substantially increased. Due to these negative situations, it can be said that it is important to examine the attitudes and anxieties of prospective teachers towards the teaching profession (Serin et al., 2015). 
Figure 2

The Most Frequently Used Keywords in Studies Conducted on the Anxiety Levels of Prospective Teachers

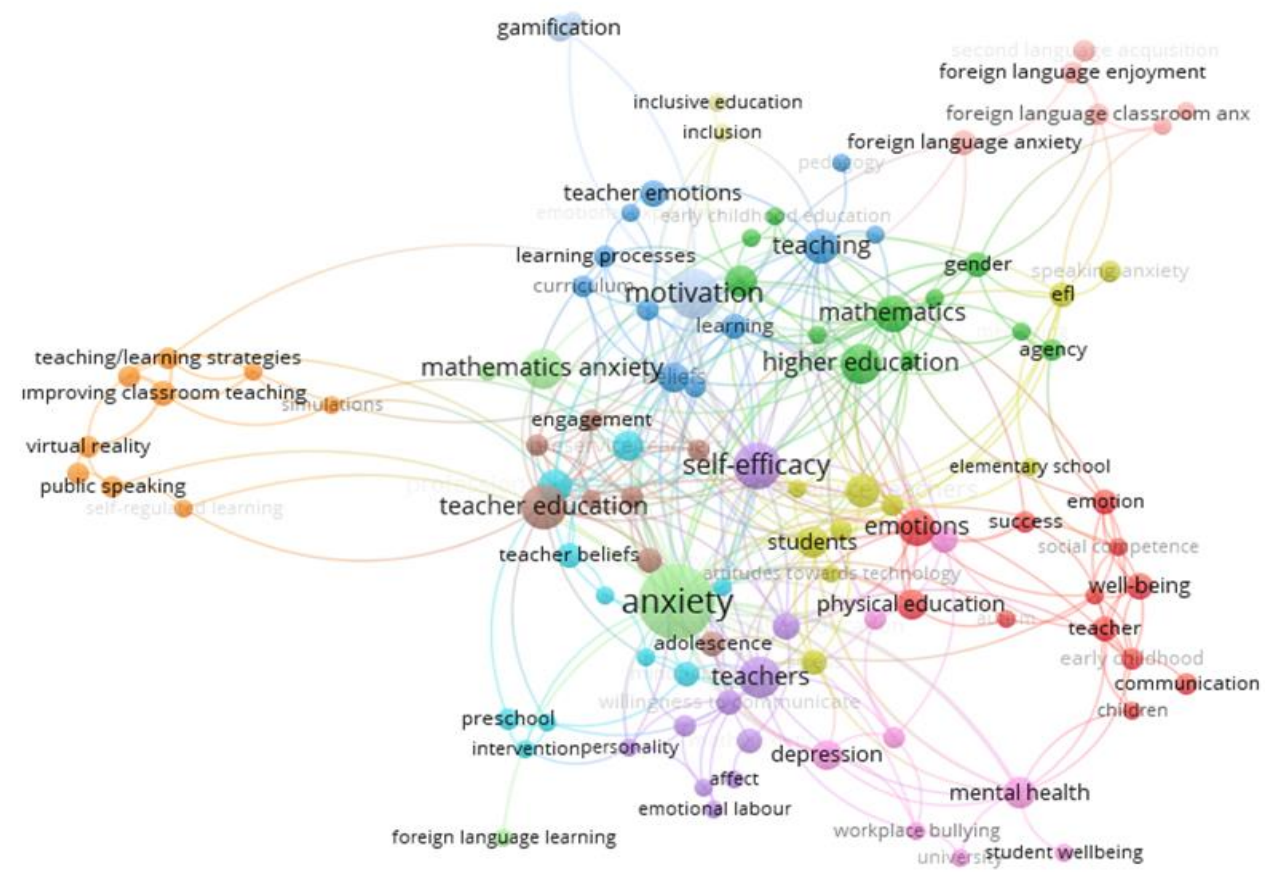

\subsection{Aim of the Study and the Research Questions}

The aim of this study was to cross-sectionally and longitudinally examine whether the attitude and anxiety levels of prospective primary school teachers towards the teaching profession differed throughout their undergraduate education. Additionally, with the qualitative data obtained from the study, the factors/experiences triggering the change in the attitudes and anxiety levels of prospective teachers towards the teaching profession were thoroughly determined. Accordingly, this study sought the answers to the following questions:

1. Do the attitude scores of the prospective primary school teachers towards the teaching profession differ based on the year they are in (cross-sectionally/longitudinally)?

2. Do the anxiety scores of the prospective primary school teachers towards the teaching profession differ based on the year they are in (cross-sectionally/longitudinally)?

3. What are the factors/experiences affecting the attitudes and anxiety levels of the prospective primary school teachers towards the teaching profession?

\section{Method}

This study was conducted in two main stages. In the first stage, the data were collected crosssectionally and analyzed. In the second stage, the attitude and anxiety levels of the participants towards the teaching profession were evaluated four different times at the end of each academic year for four years. Additionally, the participants were interviewed at the end of each academic year to determine the factors/experiences affecting their attitudes and anxiety levels towards the teaching profession. Within the scope of the study, necessary ethics permissions were obtained from the participants.

\subsection{Research Design}

\subsubsection{Study 1}

Study 1 was conducted as a cross-sectional study, which is type of study used to collect data from a predetermined sample in a single moment (Fraenkel et al., 2015). In study 1, data were collected 
from prospective primary school teachers in different years of undergraduate education with the help of certain measurement tools over a period of two weeks.

\subsubsection{Study 2}

In study 2, quantitative and qualitative methods were used together. The quantitative part of Study 2 was carried out in accordance with panel studies, which are a type of longitudinal study. Panel studies are conducted to collect data from the same sample at different times (Fraenkel et al., 2015). In Study 2, the quantitative data of the participants were collected at the end of each academic year, for a total of four years with the help of measurement tools. By doing so, it was aimed to determine what kind of change occurred in the attitude and anxiety levels of the participants towards the teaching profession. For this reason, the use of panel research was considered to be appropriate. After the quantitative data were collected, interviews were conducted with the participants at the end of each academic year. In these interviews, the factors/experiences affecting/changing the attitude and anxiety levels of the participants towards the teaching profession during that were attempted to be determined.

\subsection{Participants}

\subsubsection{Study 1}

Study 1 was conducted with a total of 1085 prospective primary school teachers studying in an undergraduate primary school teaching program. All of the participants consisted of Turkish students. The age of the participants was between 18 and 26 years old. A total of 785 of the participants $(72.4 \%)$ were female, while 300 of them (27.6\%) were male. Two hundred and twentyone participants $(20.4 \%)$ were first year students, 285 of them $(26.3 \%)$ were second year students, 299 of them $(27.6 \%)$ were third year students and 280 of them $(25.8 \%)$ were fourth year students. A total of 946 participants $(87.2 \%)$ stated that they willingly enrolled in the teaching program, while $139(12.8 \%)$ of them stated that they enrolled in the teaching program based on their placement score. Seven hundred and fifty-four participants $(69.5 \%)$ stated that they had a teacher in their immediate circles. One hundred and eighty-five (17.1\%) participants stated they had a parent that was a teacher, $163(15 \%)$ stated they had siblings who were teachers, $160(14.7 \%)$ stated they had uncles who were teachers and $146(22.7 \%)$ stated they had cousins who were teachers. This could have been influential in decisions of the participants in choosing the teaching profession. As a matter of fact, some studies have reported that the immediate circle of an individual is a determinant in the choice of profession (Abişeva, 1997; Ensari \& Hazal, 2017). However, 331 participants $(30.5 \%)$ stated that no one in their immediate circle was a teacher. Five hundred and seventy-four participants (52.9\%) stated that they had no teacher role models, 337 of them (33.1\%) stated that their primary school teacher was their role model, 79 of them $(7.3 \%)$ stated that their math teacher was their role model and the remaining 95 participants $(8.8 \%)$ stated that their role model was a teacher of another subject matter.

\subsubsection{Study 2}

Study 2 was conducted with 57 prospective primary school teachers who were studying in an undergraduate primary school teaching program. All of the participants consisted of Turkish students. The age of the participants was between 18 and 22 years old. The number of participants at the beginning of the study was 65 . However, some participants were excluded from the sample due to the conditions such as transferring to other universities and suspending their studies. Thirty-nine participants $(68.4 \%)$ were female, while $18(31.6 \%)$ were male. Forty-nine participants $(86 \%)$ stated that they had willingly enrolled in the primary school teaching program, while eight $(14 \%)$ participants stated that they had enrolled in the teaching program based on their placement score. Seven $(12.3 \%)$ participants stated they had a parent that was a teacher, six $(10.5 \%)$ stated they had a sibling who was a teacher, $10(17.5 \%)$ stated they had an uncle who was a teacher and $16(28.1 \%)$ stated they had cousins who were teachers. On the other hand, 18 participants $(31.6 \%)$ 
stated that they had no one in their immediate circle who was a teacher. Twenty-six participants $(45.6 \%)$ stated that they had no teacher role models, 20 of them $(35.1 \%)$ stated that their primary school teacher was their role model, nine of them $(15.8 \%)$ stated that their math teacher was their role model and the two remaining participants $(3.5 \%)$ stated that their English teacher was their role model.

\subsection{Data Collction Techniques and Tools}

The quantitative data for Studies 1 and 2 was collected by applying the Attitude Scale Regarding Teaching, which was developed by Erkuş et al. (2000) and the Occupational Anxiety Scale for Prospective Teachers, which was developed by Cabı and Yalçınalp (2013). As the scales were developed for prospective teachers in similar samples, their application for the present study was considered to be appropriate. In addition, the fact that the scales are continuously used in studies indicated that they provided valid and reliable estimations. The necessary permission to use the scales in the present study was obtained from the developers of the scales via e-mail.

\subsubsection{Attitude scale regarding teaching}

In order to demonstrate the changes in the attitudes of the prospective teachers towards the teaching profession, the Attitude Scale Regarding Teaching (Erkuş et al., 2000) was applied. This scale consists of 23 items and has a single-factor structure. The factor loading values of the scale items are between .56 and .79 , while the total item correlations are between .45 and .79 . The Cronbach's alpha internal consistency coefficient of the scale was calculated as .99. The items of the scale are graded in 5-point Likert format (1=Not appropriate at all, 2=Inappropriate, 3=Undecided, $4=$ Appropriate, $5=$ Absolutely appropriate). Therefore, the minimum score that can be obtained from the scale is 23 , while the maximum score is 105 . Some of the items in the scale are as follows: I would prefer to be a teacher despite all the difficulties, I love teaching a lot, I never think of teaching, I believe that I was born to be a teacher. Within the scope of the study, the validity and credibility analyses of the scale were conducted repeatedly. First, the structure conformity of the scale was tested by applying a confirmatory factor analysis with the obtained data set. The obtained values were found to indicate a good conformity $\left(\chi^{2} / d f=2.39\right.$, RMSEA $=.056$; NFI=.97, $\mathrm{NNFI}=.98, \mathrm{CFI}=.98, \mathrm{IFI}=.98, \mathrm{RFI}=.97, \mathrm{RMR}=.038, \mathrm{SRMR}=.039, \mathrm{GFI}=.92, \mathrm{AGFI}=.90)$. The Crobach's alpha internal consistency coefficient regarding the whole scale was calculated as .95. The analyses results proved that the scale was able to deliver valid and reliable estimations.

\subsubsection{Occupational anxiety scale for prospective teachers}

The Occupational Anxiety Scale for Prospective Teachers was applied to acquire information regarding the anxieties of prospective teachers about their profession (Cabı \& Yalçınalp, 2013). As a result of the exploratory factor analysis (EFA) conducted by the researchers who developed the scale, a structure consisting of 45 items and eight sub-dimensions explaining $65.724 \%$ of the total variance was obtained. The item factor loading values of the items in the factors are between .49 and .90, while the item-total correlations are between .44 and .67. It was reported that the Cronbach's alpha internal consistency coefficients of the sub-dimensions were between 0.67 and 0.94, while the internal consistency coefficient for the whole scale was calculated as .95 . The items of the scale are graded in 5-point Likert format (1=Very Worried, 2=Quite Worried, 3=Partially Worried, $4=$ Very Little Worried, $5=$ Not worried). Factors and some of the items in the scale are as follows.

Task-Centered Anxiety. I worry about my students finding my knowledge inadequate, I worry about not being enough for an effective classroom management.

Economic/Social-Centered Anxiety. I worry about degrease in the respect for my profession in the society, I am concerned about the limited social and cultural activities in the place where I work. Student/Communication-Centered Anxiety. I worry about not being able to deal with problematic students, I worry about not being able to communicate effectively with my students. 
Colleague and Parent-Centered Anxiety. I worry about not being able to communicate effectively with my colleagues, The possibility of families seeing me as a failure worries me.

Self-Improvement-Centered Anxiety. I worry about not being able to improving myself by thinking that the knowledge and skills I have learned will be enough for me,

Assignment-Centered Anxiety. I worry about not being assigned to anywhere as a result of the assignment exam, I worry about not being assigned to a place I want.

Adaptation-Centered Anxiety. I worry about not being able to adapt to the environment I work in.

School Management-Centered Anxiety. I worry about not being treated fairly by the school administration, I am worried about having problems with the school administration.

Within the scope of the study, the validity and credibility analyses of the scale were conducted repeatedly. In this context the second level of confirmatory factor analysis was applied and the confirmatory of the scale's factor structure was tested. Result of the obtained data indicated a good conformity $\left(\chi^{2} / d f=2.60, \mathrm{NFI}=.97, \mathrm{NNFI}=.98, \mathrm{CFI}=.97, \mathrm{RFI}=.96, \mathrm{IFI}=.97, \mathrm{GFI}=.91, \mathrm{AGFI}=.88\right.$, $\mathrm{RMR}=.069$, SRMR=.054, RMSEA=.061). The Cronbach's alpha internal consistency coefficient regarding the whole scale was calculated as .94. It was observed that the Cronbach's alpha internal consistency coefficients of the sub-dimensions were between 0.63 and 0.88 . This shows the power of the relationships between the sub-dimensions. Additionally, the fact that the mentioned values were not .90 and above proved that there was no multiple correlation problem and therefore each sub-dimension evaluated a different feature. In this context it can be said that this scale will provide valid and reliable evaluations.

\subsubsection{Semi-structured interview form}

In order to obtain the qualitative data for Study 2, interviews were conducted with the participants $(n=57)$ at the end of each academic year. The data were collected through the semi-structured interview form developed by the researchers. An elaborative literature review was carried out before the form was developed. As a result, the factors affecting the attitudes and anxieties of teachers and prospective teachers towards the profession were identified. By turning these factors into open-ended questions, the first draft of the form was prepared. Additionally, new questions were added to the form after acquiring the opinions of 15 primary school teachers, who were actively teaching during that time. The draft form's comprehensibility was tested by submitting it to 10 prospective teachers for their opinions. In line with the feedback received, the structure of some of the questions was changed and the necessary language editing was applied. In the last stage, the draft form was submitted to a total of five expert lecturers, three of whom are primary school teachers, one of whom is an expert in evaluation and one in the field of vernacular language teaching. As a result of the feedback received, two questions were added and one question was removed from the form. Therefore, the number of questions in the form was increased to 18. Additionally, the language of one of the questions was edited due to the fact that it was incomprehensible. Some of the questions in the semi-structured interview form are as follows: How did the training you received from the university this year affect your attitude/anxiety towards the profession?, Who were the people influential in changing your attitude/anxiety towards the profession and how did they affect you? and How have your experiences in the last year affected your attitude/anxiety towards the profession?.

The interviews were conducted through appointments, the times of which were determined by the participants. The interviews were recorded using a voice recorder after obtaining the permission of the participants. The voice recordings were transcribed and transferred to a computer environment. The data were immediately analysed and new questions were added to the form. In all of the addition processes, the opinions of the experts were acquired again. The duration of the interviews varied between 14 and 33 minutes. 


\subsection{Data Analysis}

\subsubsection{Study 1}

Descriptive and predictive statistics were applied in the data analysis of Study 1 . The general situation was presented with the descriptive statistics. Firstly, the credibility of the data set was analysed and the univariate normal distribution assumption, a prerequisite for parametric analysis, was examined. The data's normality was analysed based on the grade levels of the participants in terms of both their attitudes towards the teaching profession and anxiety scores. It was observed that the kurtosis and skewness values of the data in each group were close to 0 . In addition, arithmetic average, mode and median relationship, histogram and, PP and QQ graphs were analysed. As a result of the analyses, it was concluded that the distribution of the data of Study 1 was normal.

In the predictive statistics part, in order to determine whether the attitude and anxiety scores of the prospective teachers towards the teaching profession changed based on their grade levels, multivariate analysis of variance (MANOVA) was conducted. It has been emphasized in the literature that both univariate normal distribution and multivariate normal distribution should be provided for multivariate analyses (Field, 2013). In order to check whether multivariate normal distribution was ensured, the Mahalonobis distance coefficient was calculated and the Cook's and Leverage values were examined. As a result of the analysis, it was observed that the data set met the multivariate normal distribution assumption. In order to determine which groups were in favour of the difference between the averages and whether it was significant or not the Bonferroni test was applied. Field (2013) emphasized that the Bonferroni test should be applied especially when the sphericity assumption was violated. Field, also reported that applying the Bonferroni test was the most influential test in terms of statistical and Type 1 errors among comparison tests. The necessary assumptions for the analysis were provided. The significance value was considered as .005 after the Bonferroni correction.

\subsubsection{Study 2}

Descriptive and predictive statistics were applied in the data analysis of Study 2. The credibility of the data set was checked and the assumptions of univariate and multivariate normal distribution were tested. As a result of the analyses, it was determined that the data set demonstrated normal distribution. In the predictive statistics part of Study 2, analysis of variance (ANOVA) was applied for the repeated evaluations and it was determined whether the attitude and anxiety scores of the participants towards the teaching profession changed throughout their education. In order to compare the differences between the evaluations the Bonferroni test was applied. The necessary assumptions for the analysis were provided. Field (2013) stated that when interpreting ANOVA analysis results for repeated evaluations, in cases where the sphericity assumption is violated, the Greenhouse-Geisser epsilon value should be checked and the F value and a significance level of this statistic should be reported. However, in the analysis of the qualitative data obtained in Study 2, content analysis was applied. Firstly, the data were transcribed and encoded by the researchers. While determining the codes and categories, the literature and data set can be used or both methods can be used together (Henry \& Moscovici, 1968). In this study, both the literature support and the data set were used in determining the codes and categories. In addition, we sought the opinions of three field experts for the suitability of the codes and categories. Then, approximately $40 \%$ of the same data was encoded by an expert lecturer and the consistency between the codes was checked. The index of fit between the codes was calculated with the Cohen Kappa formula and determined to be .85 . Miles and Huberman (1994) emphasized that when this value is .80 and above, the credibility between the codes is sufficient. In codes where consensus could not be reached, the researcher and the expert carried out reviews again. As a result of these reviews, some codes were not changed, while others were changed or removed. In addition, the codes obtained as a result of the qualitative data analysis were submitted to the participants for confirmation and 
the probable errors were removed. When presenting direct quotations from the opinions of the participants the pseudonymous given to the participants such as P1 and P2, were used.

\section{Results}

\subsection{Results of Study 1}

The attitude scale used in the study consisted of only one dimension. The anxiety scale had eight sub-dimensions. In order to determine in which sub-dimensions the changes in the anxiety scores towards the teaching profession occurred, both the total anxiety scores and the anxiety scores obtained from the sub-dimensions were included in the analysis. The descriptive results of Study 1 are presented in Table 1.

Table 1

Descriptive Results of Study 1

\begin{tabular}{|c|c|c|c|c|c|c|c|c|}
\hline \multirow[t]{2}{*}{ Grade level } & \multicolumn{2}{|c|}{ 1st Year } & \multicolumn{2}{|c|}{ 2nd Year } & \multicolumn{2}{|c|}{ 3rd Year } & \multicolumn{2}{|c|}{ 4th Year } \\
\hline & $\bar{X}$ & $S D$ & $\bar{X}$ & $S D$ & $\bar{X}$ & $S D$ & $\bar{X}$ & $S D$ \\
\hline Attitude score & 57.27 & 7.5 & 57.14 & 7.24 & 55.54 & 8.8 & 56.6 & 4.98 \\
\hline Total anxiety score & 141.19 & 30 & 152.98 & 24.73 & 126.38 & 21.96 & 111.53 & 21.94 \\
\hline \multicolumn{9}{|c|}{ Anxiety Scale Sub Dimensions } \\
\hline Task-centered & 49.47 & 10.1 & 55.36 & 8.68 & 33.93 & 6.05 & 22.66 & 5.76 \\
\hline $\begin{array}{l}\text { Economic/social- } \\
\text { centered }\end{array}$ & 23.47 & 6.96 & 23.83 & 5.86 & 24.76 & 6.01 & 25.06 & 5.57 \\
\hline $\begin{array}{l}\text { Student/communication- } \\
\text { centered }\end{array}$ & 17.33 & 5.13 & 18.77 & 5.48 & 16.24 & 4.54 & 12.44 & 3.34 \\
\hline $\begin{array}{l}\text { Colleague/parent- } \\
\text { centered }\end{array}$ & 12.37 & 3.86 & 12.76 & 3.66 & 13.02 & 3.95 & 13.44 & 3.2 \\
\hline $\begin{array}{l}\text { Self-improvement- } \\
\text { centered }\end{array}$ & 10.75 & 3.53 & 11.3 & 3.82 & 10.7 & 3 & 9.48 & 3.05 \\
\hline Assignment-centered & 10.26 & 2.36 & 10.7 & 2.31 & 10.99 & 2.76 & 11.79 & 2.82 \\
\hline Adaptation-centered & 8.21 & 2.03 & 8.7 & 2.29 & 7.93 & 1.83 & 7.54 & 1.96 \\
\hline $\begin{array}{l}\text { School management- } \\
\text { centered }\end{array}$ & 9.3 & 1.91 & 9.65 & 1.86 & 9.34 & 1.76 & 9.49 & 1.75 \\
\hline
\end{tabular}

The average attitude scores of the participants were found to be the highest in the first year $(\bar{X}=57.27, S D=7.5)$, while they were lowest $(\bar{X}=55.54, S D=8.8)$ in the third year. It can be seen that the total anxiety scores reached the highest level in the second year $(\bar{X}=152.98, S D=24.73)$ and dropped to the minimum level $(\bar{X}=111.53, S D=21.94)$ in the fourth year. The attitude scores of the prospective primary school teachers did not shown much change over the grade levels. However, differences between the grade levels were found. In order to determine in which subdimensions this difference occurred, the change in the sub-dimensions of the anxiety scale had to be examined. When the averages in the sub-dimensions were analyzed, it was determined that the task-centered anxiety scores were high in the first year $(\bar{X}=49.47, \mathrm{SD}=10.01)$ and second year $(\bar{X}=55.36, S D=8.68)$, started to decrease in the third $(\bar{X}=33.93, S D=6.05)$ and dropped to the minimum level in the fourth year $(\bar{X}=22.66, S D=5.76)$. Another striking change regarding the average scores occurred in the student communication-centered anxiety sub-dimension. It was determined that the average scores reached the maximum level $(\bar{X}=18.77, S D=5.48)$ in the second year and dropped to the minimum level $(\bar{X}=12.44, S D=3.34)$ in the fourth year. Although the averages differed less in the other sub-dimensions of the anxiety scale, in order to determine whether these differences were significant the MANOVA results given in Table 2 were examined. As a result of the analysis, it was determined that the model was significant, that is, the averages of the dependent variables differed significantly based on the groups (Pillai's Trace $\left.(\mathrm{V})=.739, \mathrm{~F}_{(27,3225)}=39.036, \mathrm{p}=.000, \mathrm{\eta}^{2}=.25\right)$. 
Table 2

Comparing the Attitude and Anxiety Levels of the Prospective Teachers towards the Teaching Profession based on their Grade Levels (Cross-sectional)

\begin{tabular}{|c|c|c|c|c|c|c|c|}
\hline Dependent Variable & $\begin{array}{l}\text { Sum of } \\
\text { Squares }\end{array}$ & $d f$ & $\begin{array}{l}\text { Mean } \\
\text { Square }\end{array}$ & $F$ & $p$ & $\eta^{2}$ & Difference \\
\hline Attitude & 520.86 & 3 & 173.62 & 3.268 & .021 & .009 & $1>2>4>3$ \\
\hline Error & 57432.52 & 1081 & 53.13 & & & & \\
\hline Anxiety & 270594.82 & 3 & 90198.27 & 148.396 & .000 & .292 & $2>1>3>4$ \\
\hline Error & 657055.06 & 1081 & 607.82 & & & & \\
\hline \multicolumn{8}{|l|}{ Anxiety Scale Sub-dimensions } \\
\hline Task-centered & 182133.45 & 3 & 60711.15 & 617.881 & .000 & .632 & $2>1>3>4$ \\
\hline Error & 106215.86 & 1081 & 98.26 & & & & \\
\hline Economic/social-centered & 677.65 & 3 & 225.88 & 6.120 & .000 & .017 & $4>3>2>1$ \\
\hline Error & 39897.61 & 1081 & 36.91 & & & & \\
\hline $\begin{array}{l}\text { Student/communication- } \\
\text { centered }\end{array}$ & 6125.61 & 3 & 2041.87 & 54.276 & .000 & .131 & $2>1>3>4$ \\
\hline Error & 40666.99 & 1081 & 37.62 & & & & \\
\hline Colleague/parent-centered & 159.51 & 3 & 53.17 & 2.740 & .042 & .008 & $4>3>2>1$ \\
\hline Error & 20977.60 & 1081 & 19.41 & & & & \\
\hline Self-improvement-centered & 497.35 & 3 & 165.78 & 8.210 & .000 & .022 & $2>1>3>4$ \\
\hline Error & 21828.18 & 1081 & 20.19 & & & & \\
\hline Assignment-centered & 292.18 & 3 & 97.39 & 10.419 & .000 & .028 & $4>3>2>1$ \\
\hline Error & 10105.07 & 1081 & 9.35 & & & & \\
\hline Adaptation-centered & 200.66 & 3 & 66.89 & 7.264 & .000 & .020 & $2>1>3>4$ \\
\hline Error & 9954.56 & 1081 & 9.21 & & & & \\
\hline School management-centered & 20.53 & 3 & 6.84 & .859 & .462 & .002 & $2>4>3>1$ \\
\hline Error & 8610.81 & 1081 & 7.97 & & & & \\
\hline
\end{tabular}

Table 2 shows that the attitude scores of the participants did not change significantly based on the grade level $\left(\mathrm{F}_{(3,1081)}=3.268\right.$, Mean Squared-Error $\left.(\mathrm{MSE})=98.26, \mathrm{p}=.021, \mathrm{\eta}^{2}=.009\right)$. However, it was observed that the total anxiety scores of the prospective teachers differed significantly based on their grade level $\left(\mathrm{F}_{(3,1081)}=148.396, M S E=607.82, \mathrm{p}=.000, \mathrm{\eta}^{2}=.292\right)$. The findings suggested that approximately $29 \%$ of the changes in the anxiety scores could be explained by the grade level variable. In other words, grade level was found to have a great effect on the anxiety scores of the prospective teachers. In addition, the findings also revealed that the anxiety scores of the prospective teachers were high in the first two years and decreased in the last two years. The PostHoc test results showed that this differentiation was significant among all grade levels. In order to understand in which sub-dimensions the significant differentiation in the anxiety scores were affected by the change, the changes in the sub-dimensions were examined. When Table 2 is examined, it can be seen that there is a significant difference in the task-centered $\left(\mathrm{F}_{(3,1081)}=617.881\right.$, MSE =98.26, $\left.\mathrm{p}=.000, \eta^{2}=.632\right)$, economic/social-centered $\left(\mathrm{F}_{(3,1081)}=6.120, \quad M S E=36.91, \mathrm{p}=.000\right.$, $\left.\eta^{2}=.017\right)$, student/communication-centered $\left(\mathrm{F}_{(3,1081)}=54.276, M S E=37.62, \mathrm{p}=.000, \eta^{2}=.131\right)$, selfimprovement-centered $\left.\quad\left(\mathrm{F}_{(3,}, 1081\right)=8.210, \quad M S E=20.19, \mathrm{p}=.000, \mathrm{\eta}^{2}=.022\right)$, assignment-centered $\left(\mathrm{F}_{(3,1081)}=10.419, M S E=9.35, \mathrm{p}=.000, \eta^{2}=.028\right)$ and adaptation-centered $\left(\mathrm{F}_{(3,1081)}=7.264, M S E=9.21\right.$, $\left.\mathrm{p}=.000, \mathrm{\eta}^{2}=.020\right)$ anxiety sub-dimensions. Moreover, there was no significant difference in the colleague and parent-centered anxiety $\left(\mathrm{F}_{(3,1081)}=2.740, M S E=19.41, \mathrm{p}=.042, \eta^{2}=.008\right)$ and school management-centered anxiety $\left(\mathrm{F}_{(3,1081)}=.859, M S E=7.97, \mathrm{p}=.462, \eta^{2}=.002\right)$ sub-dimensions. The findings revealed that grade level explained approximately $63 \%$ of the variance in the taskcentered anxiety sub-dimension. However, it also explained $13 \%$ of the variance in the student communication-centered anxiety sub-dimension. Accordingly, when the partial Eta squared values are taken into consideration, it can be stated that grade level had a great influence on the taskoriented and student communication-centered anxiety sub-dimensions. The findings showed that 
the task-centered anxiety, student/communication-centered anxiety and adaptation-centered anxiety scores decreased as the grade level increased. The analyses revealed that this change was significant for upper-lower grade levels $(p=.000)$. It can be said that the economic/social-centered and self-improvement-centered average scores demonstrated irregularities. However, it was understood that the assignment-centered anxiety scores increased as the grade level increased. It was pointed out that the differentiation in these sub-dimensions was significant and in favor of the fourth-year students $(\mathrm{p}=.000)$.

\subsection{Results of Study 2}

In this section, the results of the study carried out longitudinally, namely Study 2, are presented. The descriptive results of Study 2 are given in Table 3.

Table 3

Descriptive Statistics Findings of Study 2

\begin{tabular}{lcccccccc}
\hline \multirow{2}{*}{ Grade level } & \multicolumn{3}{c}{ 1st Year } & \multicolumn{2}{c}{ 2nd Year } & \multicolumn{2}{c}{ 3rd Year } & \multicolumn{2}{c}{ 4th Year } \\
\cline { 2 - 9 } & $\bar{X}$ & $S D$ & $\bar{X}$ & $S D$ & $\bar{X}$ & $S D$ & $\bar{X}$ & $S D$ \\
\hline Attitude score & 57.75 & 7.08 & 57.75 & 6.62 & 55.46 & 6.34 & 57.21 & 5.17 \\
Total anxiety score & 168.28 & 17.23 & 165 & 20.5 & 131.14 & 12.86 & 104.98 & 18.23 \\
\hline Anxiety Scale Sub-dimensions & & & & & & & & \\
\hline Task-centered & 53.63 & 9.18 & 55.75 & 7.08 & 35.96 & 11.29 & 20.82 & 8.71 \\
Economic/social-centered & 28.35 & 5.38 & 27.82 & 5.02 & 24.12 & 4.73 & 24.04 & 5.78 \\
Student/communication & 22.21 & 5.33 & 22.09 & 6.35 & 17.07 & 4.24 & 11.30 & 4.72 \\
centered & 16.02 & 4.24 & 13.58 & 5.24 & 13.26 & 2.79 & 11.98 & 3.45 \\
Colleague/parent-centered & 17 & 2.69 & 12.56 & 4.95 & 11.47 & 3.53 & 6.28 & 1.91 \\
Self-improvement-centered & 9.26 & 3.44 & 11.33 & 3.25 & 11.39 & 1.98 & 13.98 & 3.55 \\
Assignment-centered & 10.51 & 2.48 & 9.82 & 3.49 & 8.30 & 2.13 & 7 & 1.69 \\
Adaptation-centered & 11.32 & 2.35 & 10.12 & 3.12 & 9.56 & 1.96 & 9.58 & 1.69 \\
School management-centered & & & & & & & &
\end{tabular}

Table 3 shows that the attitude scores of the participants did not changed much in four years. It was observed that the total anxiety scores of the participants was high in the first year $(\bar{X}=168.28, S D=17.23)$, gradually decreased in the following years and regressed to the minimum level in the fourth year $(\bar{X}=10.98, S D=18.23)$. When the table was analyzed, it was determined that apart from the assignment-centered anxiety sub-dimension, the averages of all of the sub-dimensions of the anxiety scale decreased as the grade level increased. One of the most striking findings was the change in the task-centered anxiety average scores as there was approximately 23 points difference between the first year $(\bar{X}=53.63, S D=9.18)$ and last year scores $(\bar{X}=20.82, S D=8.71)$. The student/communication-centered anxiety scores began to decrease as of the first year $(\bar{X}=22.21, S D=5.33)$ and dropped to the minimum level in the fourth year $(\bar{X}=11.30, S D=4.72)$. Another striking change is the one that occurred in the selfimprovement-centered anxiety averages as it was observed that these averages reached the maximum level $(\bar{X}=17, S D=2.69)$ in the first year and dropped to the minimum level $(\bar{X}=6.28, S D=1.91)$ in the fourth year. In order to be able to determine whether the change in the average scores was significant, ANOVA was carried out for the repeated evaluations and the analysis results are presented in Table 4. 
Table 4

Comparing the Attitude and Anxiety Levels of the Prospective Teachers towards the Teaching Profession according to Grade Level (Longitudinal)

\begin{tabular}{|c|c|c|c|c|c|c|c|}
\hline Dependent Variable & $\begin{array}{l}\text { Sum of } \\
\text { Squares }\end{array}$ & $d f$ & $\begin{array}{l}\text { Mean } \\
\text { Square }\end{array}$ & $F$ & $p$ & $\eta^{2}$ & Difference \\
\hline Attitude & 202.83 & 2.93 & 69.14 & 1.739 & .162 & .030 & $1=2>4>3$ \\
\hline Error & 6530.68 & 164.28 & 39.76 & & & & \\
\hline Anxiety & 154322.561 & 2.46 & 62651.63 & 183.569 & .000 & .766 & $1>2>3>4^{*}$ \\
\hline Error & 47077.94 & 137.94 & 341.29 & & & & \\
\hline \multicolumn{8}{|l|}{ Anxiety Scale Sub-dimensions } \\
\hline Task-centered & 46082.56 & 2.61 & 17631.02 & 176.707 & .000 & .759 & $2>1>3>4$ \\
\hline Error & 14603.94 & 146.37 & 99.78 & & & & \\
\hline Economic/social-centered & 914.12 & 2.56 & 360.96 & 11.742 & .000 & .173 & $1>2>3>4$ \\
\hline Error & 4407.13 & 143.37 & 30.74 & & & & \\
\hline $\begin{array}{l}\text { Student/communication- } \\
\text { centered }\end{array}$ & 4565.98 & 3 & 1521.99 & 56.777 & .000 & .503 & $1>2>3>4$ \\
\hline Error & 4503.52 & 168 & 26.81 & & & & \\
\hline $\begin{array}{l}\text { Colleague and parent- } \\
\text { centered }\end{array}$ & 485.98 & 3 & 161.99 & 10.967 & .000 & .164 & $1>2>3>4$ \\
\hline Error & 2481.52 & 168 & 14.77 & & & & \\
\hline Self-improvement-centered & 3316.58 & 2.54 & 1306.3 & 91.597 & .000 & .621 & $1>2>3>4$ \\
\hline Error & 2027.68 & 142.18 & 14.26 & & & & \\
\hline Assignment-centered & 638.77 & 2.69 & 237.41 & 22.466 & .000 & .286 & $4>3>2>1$ \\
\hline Error & 1592.23 & 150.67 & 10.57 & & & & \\
\hline Adaptation-centered & 422.65 & 3 & 140.88 & 16.254 & .000 & .225 & $1>2>3>4$ \\
\hline Error & 1456.11 & 168 & 8.67 & & & & \\
\hline School management-centered & 115.84 & 2.49 & 46.55 & 6.606 & .001 & .106 & $1>2>4>3$ \\
\hline Error & 981.91 & 139.34 & 7.05 & & & & \\
\hline
\end{tabular}

Table 4 shows that the difference in the attitude score averages of the participants was not statistically significant $\left(\mathrm{F}_{(2.93,164.28)}=1.739, M S E=39.76, \mathrm{p}=.162, \mathrm{n}^{2}=.030\right)$. It was observed that the repeated evaluation results of the total anxiety scores demonstrated a significant difference $\left(\mathrm{F}_{(2.46,137.94)}=183.569, \mathrm{MSE}=341.29, \mathrm{p}=.000, \mathrm{\eta}^{2}=.766\right)$. That is, the anxiety scores of the participants towards the teaching profession decreased significantly as the grade level increased. The increasing grade level of the participants had a great influence on their anxiety scores.

The comparison of the four-year evaluations revealed that the anxiety levels of the participants were high in the first year but decreased in the following years. The comparison of the results demonstrated that there was no difference between the first and second years and that the anxiety scores of the participants in the third and fourth years differed from each other significantly and from the averages of the first two years $(p=.000)$. An analysis was conducted for every subdimension of the anxiety scale and their effect sizes were reported. When Table 4 is examined, it can be seen that the sub-dimension with the highest level of effect in the change in the anxiety scores was the task-centered anxiety $\left(\mathrm{F}_{(2.61,146.37)}=176.707, M S E=99.78, \mathrm{p}=.000, \eta^{2}=.759\right)$ subdimension. The task-centered anxiety scores were at a high level in the first years, however they decreased in the following grade levels. The comparison of the results revealed that the difference between the first- and second-year averages was not significant, but that the difference between the third- and fourth-year averages and the averages of the first two years was significant $(p=.000)$. This was the same for the average scores of the economic/social-centered anxiety $\left(\mathrm{F}_{(2.56,143.37)}=11.742, \mathrm{MSE}=30.74, \mathrm{p}=.000, \mathrm{\eta}^{2}=.173\right)$ and student/communication-centered anxiety $\left(\mathrm{F}_{(3,168)}=56.777, M S E=26.81, \mathrm{p}=.000, \mathrm{\eta}^{2}=.503\right)$ sub-dimensions. It can be said that the grade levels of the participants had a high effect on the change in both sub-dimensions. Another sub-dimension in which the difference was significant, was the colleague and parent-centered anxiety $\left(F_{(3,168)}=22.466\right.$, 
MSE =14.77, $\left.\mathrm{p}=.000, \eta^{2}=.164\right)$ sub-dimension. The comparison of the results showed that the difference between the first, second, third- and fourth-year averages was significant $(p=.000)$. It was found that the self-improvement-centered anxiety scores $\left(\mathrm{F}_{(2.54,142.18)}=91.597, M S E=14.26\right.$, $\left.\mathrm{p}=.000, \mathrm{\eta}^{2}=.621\right)$ and assignment-centered anxiety scores $\left(\mathrm{F}_{(2.69,150.67)}=22.466, M S E=10.57, \mathrm{p}=.000\right.$, $\eta^{2}=.286$ ) demonstrated significant differences based on the grade levels. It was observed that the Eta square values for both sub-dimensions indicated a high effect level. It can be said that the selfimprovement-centered anxiety scores of the participants decreased as the grade level increased, while the assignment-centered anxiety scores increased as the grade level increased. It was determined that the average scores of the second, third and fourth years for both sub-dimensions significantly differed from the average of the first year $(p=.000)$. It was also demonstrated that the adaptation-centered anxiety scores of the participants differed significantly based on their grade level $\left(\mathrm{F}_{(3,168)}=16.254, \mathrm{MSE}=8.67, \mathrm{p}=.000, \mathrm{\eta}^{2}=.225\right)$. The adaptation-centered anxiety scores of the participants decreased as the grade level increased. This differentiation between the averages of the first two years and the averages of the last two years was significant. It was also significant between the averages of the third and first years $(p=.000)$. A significant difference was determined in the school management-centered anxiety sub-dimension $\left(\mathrm{F}_{(2.49,139.34)}=6.606, M S E=7.05, \mathrm{p}=.001\right.$, $\left.\eta^{2}=.106\right)$. The comparison of the results showed that there was a significant difference between the average of the first year and the averages of the other years in terms of this sub-dimension.

Interviews were carried out with the participants at the end of each academic year. The data set obtained as a result of the interviews was subjected to content analysis and as a result the codes and categories presented in Table 5 were obtained. The distribution by years was not included in the presentation of the findings as only the most emphasized points were taken into consideration.

Table 5

Factors/Experiences Affecting the Attitudes and Anxiety Levels of the Participants towards the Teaching Profession

\begin{tabular}{|c|c|c|c|}
\hline Sub-Category & Code & $n$ & $\%$ \\
\hline \multirow[t]{5}{*}{ Attitude } & Conscious choice & 15 & 26 \\
\hline & Score based placement & 10 & 18 \\
\hline & Lecturers sharing their experiences & 8 & 14 \\
\hline & Influence of field education courses & 7 & 12 \\
\hline & $\begin{array}{l}\text { Influence of internship courses (school experience and teaching } \\
\text { practices) }\end{array}$ & 12 & 21 \\
\hline \multirow[t]{15}{*}{ Anxiety } & The anxiety state before the choice of placement & 40 & 70 \\
\hline & Lecturers sharing their experiences & 24 & 42 \\
\hline & $\begin{array}{l}\text { Influence of the field education and vocational knowledge } \\
\text { courses (general) }\end{array}$ & 10 & 18 \\
\hline & Inclusive education course & 23 & 40 \\
\hline & Primary reading and writing teaching course & 25 & 44 \\
\hline & Math teaching course & 24 & 42 \\
\hline & Classroom management course & 26 & 46 \\
\hline & Multigrade class teaching course & 27 & 47 \\
\hline & Instructional technology course & 10 & 18 \\
\hline & Teaching principles and methods & 12 & 21 \\
\hline & $\begin{array}{l}\text { Influence of internship courses (school experience and teaching } \\
\text { practice) }\end{array}$ & 55 & 96 \\
\hline & Advisor teacher observation & 17 & 30 \\
\hline & Meeting students & 34 & 60 \\
\hline & Direct experiences & 50 & 88 \\
\hline & Assignment anxiety & 45 & 79 \\
\hline
\end{tabular}


The opinions of the participants towards the teaching profession were collected under the attitude and anxiety categories (sub-category) as summarized in Table 5. Fifteen of the participants $(26 \%)$ justified that they either liked the profession before choosing it or chose the profession based on their scores and stated that there was not much change in their attitudes towards the profession. P2's statement on the topic was as follows: 'I chose this department willingly. I already loved teaching. That is why the four years I spent at university have not changed my attitude significantly.' Some of the participants $(14 \%)$ stated that lecturers sharing their experiences affected their attitudes towards the profession, while others $(12 \%)$ stated that the field education courses positively changed their attitudes towards the profession.

I was neutral at first. Thanks to the training I received, I have realized the colorful sides of the profession. The idea of teaching someone something made me love the profession. Doing an internship gave us a real-life experience and we got a little taste of what it is like (P23).

As can be understood from P23's statement some participants $(21 \%)$ stated that the most important factor in changing their attitudes was their experiences they gained through internships. This was also supported by the statement of P8:

I feel really happy when I am with the kids in the teaching practice course. I have to admit that the experiences I gained during the internship made me develop positive emotions towards the profession. Because adding something to the kids makes me really happy (P8).

However, the majority of the participants stated that their attitudes towards the profession had not changed significantly over the years they studied. The participants whom stated that their attitudes towards the profession did change, also stated that they did not experience a considerable change.

Approximately $70 \%$ of the participants stated that they had a high level of anxiety before starting studying in the primary school teaching program. This anxiety could be caused by the fact that it is difficult to teach younger students reading, writing and basic math skills and the probability of working in the multigrade class.

Even when I hadn't decided yet, my anxiety towards the profession was quite high. Because I did not know what I was going to do and how to deal with it. It felt so terrifying to take responsibility for students, to teach them something, to prepare them for life (P24).

P24's statement is an example to this situation.

When people do not know what to encounter, their anxiety increases. That was the exactly what I experienced. Sometimes I could guess the issues I would encounter but the solutions were unclear. We were given solid examples in some aspects by lecturers sharing their experiences with us and this reduced my anxiety (P52).

As it can be understood by P52's statement of some of the participants (42\%) emphasized that lecturers sharing their experiences reduced their anxiety towards the profession during the years they received education. Ten participants stated that the field education and vocational knowledge courses they took were influential on reducing their anxiety regarding the profession but did not specifically mention the names of the courses. However, some participants directly stated which field education and vocational knowledge courses reduced their anxiety levels. The prominent courses in the table were teaching in multigrade classes $(47 \%)$, classroom management $(46 \%)$, teaching reading and writing $(44 \%)$ and math teaching $(42 \%)$. Direct quotation examples from the participants regarding this situation are as following:

My first assignment will most likely be to a village school. So, I will probably be teaching in a multigrade class. Imagine I was losing sleep over thinking about teaching a single class in village conditions but now I'm going to be a teacher of a multigrade class. My anxiety was mostly about being a teacher in a village and teaching a multigrade class. The most important factor in eliminating my anxiety was the teaching in multigrade classes course (P2).

At first, I was quite nervous about how I was going to handle a class. I was really afraid of students not listening or not being able to manage the classroom. With the classroom management course I took in the second grade my anxiety decreased considerably. After taking this course, I gained a 
great deal of information from how to communicate with students in a classroom to how to solve my problems (P7).

As you know, one of the most important tasks of primary school teachers is to teach their students how to read and write. I really cared about this and I had no idea how to do it. The primary reading and writing course I took allowed me to overcome my worst fear (P16).

As it can be understood by P49's following statement, some participants had anxiety about how to carry out educational activities with students with special needs. It can be understood that the field education and vocational knowledge courses were influential in reducing this particular anxiety.

I always had a fear of encountering children with special needs, not being able to notice/recognize them and not being able to meet their needs. But I have learned that recognizing them is not that hard and I learned how to deal with this (P49).

Another striking point is that approximately $96 \%$ of the participants pointed out the internship courses reduced their anxiety. This matter was emphasized by almost every participant. For example:

There is a huge difference between my anxiety level when I first started university and my current anxiety level. The most important reason for this was definitely the internship program. Doing the internship was just like realizing how great it is when you eat a meal that does not look appetizing but is actually very tasty once you try it (P17).

Thanks to the internship I had the chance to see myself in the field. This and practice courses like this brought me together with the students, so I had the chance to test myself. My self-confidence was boosted. I realized that I can carry out this profession properly. My fears have disappeared (P44).

Some participants $(30 \%)$ emphasized that observing the advisors reduced their existing anxieties about the teaching profession. For example, P3 stated 'We observed the ways the primary school teachers solved problems during our internships and this was influential on the reduction of my biggest anxieties.' In this regard it was thought that the indirect experiences the prospective teachers obtained from their mentor teachers were influential. In addition, the participants stated that being in the classroom atmosphere, meeting students $(60 \%)$ and having direct experiences (88\%) significantly reduced their anxiety levels. Direct quotes from the participants regarding this issue are as follows:

My anxieties began to disappear once I interacted with real students in a real classroom. I saw that managing students was not difficult, I could easily teach them something and the students loved me. Spending time with students actually reduced my anxieties (P30).

The first two years of my education I never felt like I was enough and I believed that I had to improve myself. I wanted to put my theoretical knowledge into practice and to do my selfassessment and see what level my competencies were. At this point, I needed to interact with students and the internship practices helped me a lot to overcome my anxieties (P27).

All of my fears started to disappear when I had time alone with the students and they called me "Teacher!". I think the most influential condition in eliminating anxiety is to interact with students in person (P1).

Seeing and experiencing everything in the field was influential in reducing my anxiety. In other words, internship practices teach you what to do when a child cries, fights, loses interest in the class or wants to play games (P14).

The qualitative findings of the study generally indicated that the anxiety participants had towards the profession decreased over time. The issue increasing the anxiety level of the participants and emphasized by four out of every five participants (79\%) was related to the assignment anxiety sub-dimension. The participants are subjected to a general exam after graduation and then they are interviewed. Regarding this, the participants, especially those in their third and fourth years, stated that they had exam anxiety. In addition, some participants stated that some of the lessons they took and some of the experiences they had, increased their anxiety levels. For example: 
For example, having an inclusive student makes my job more difficult. Any negative behavior towards that student makes me sad and causes negative situations in my classroom. I had no such fears until I encountered such a student in my internship practice. That is why some of my experiences have reduced my anxieties about the profession while others have increased them (P5).

\section{Discussion, Conclusion and Recommendations}

The purpose of this study is to determine if attitudes and anxiety levels of primary school teacher candidates regarding the teaching profession change throughout the course of their undergraduate education, both cross-sectionally and longitudinally. Answers were sought whether or not the attitudes and anxiety scores of primary school teacher candidates towards the teaching profession vary depending on the year they are in (sectional/longitudinal) and what factors/experiences influence these attitudes and anxiety scores.

As a result of Study 1 it was determined that the attitude scores of the prospective teachers towards the teaching profession did not differ significantly based on their grade level. This revealed that the attitudes of the prospective teachers towards the profession did not changed significantly throughout their education. The results of Study 2 also supported this finding. As a matter of fact, the findings in which 59 participants were included and the four-year average scores were compared also revealed that the average attitude scores of the prospective teachers did not differ significantly based on their grade level. The qualitative data obtained with regards to the change in the attitudes towards the profession revealed that the attitudes participants had prior to making a choice regarding their career did not change too much. Although some of the prospective teachers stated that they experienced a change in their attitudes, they underlined that this change was not to a great extent. In this context, it can be stated that both the quantitative and qualitative data supported one another. When the literature was examined it was observed that the results of some studies demonstrated that the attitude towards the profession of teaching changed significantly based on grade level (Çapa \& Çil, 2000; Fadlelmula, 2013), while some studies reported the contrary (Güneyli \& Aslan, 2009; Taşdemir, 2014; Uyanık, 2017). The findings of the present study supported the findings in the literature that showed that the attitudes towards teaching did not differ based on grade level.

The findings that revealed the changes in the total anxiety scores of teacher candidates based on the grade level emphasized a significant difference in accordance with grade level. This is true for both the cross-sectional and longitudinal studies. The findings also revealed that grade level had a great effect on the change in the total anxiety scores. The qualitative findings obtained as a result of the interviews supported the change in the anxiety levels of the prospective teachers. In which sub-dimensions this change happened was examined in the cross-sectional study. The findings revealed a significant change in the task-centered, student/communication-centered, personal improvement-centered and adaptation-oriented anxiety sub-dimensions. It was determined that the anxiety levels of the prospective teachers in the aforementioned sub-dimensions decreased as their grade level increased. Moreover, the effect size values showed that grade level had a great impact on the change in the task-centered and student communication-centered anxiety subdimensions. It is possible to say that the changes in the other sub-dimensions had a smaller influence. On the other hand, an increasing trend was identified towards the senior grade regarding the economic/social-centered, colleague/parent-centered and assignment-centered anxiety sub-dimensions. The statistical analysis demonstrated that this change was significant, but the impact level was low. It was also determined that there was no statistically significant difference in the colleague/parent-centered and school management-centered anxiety subdimensions. This may implicate that the anxiety levels of the prospective teachers regarding their relationships with their colleagues, parents of students and school administration did not change at all. The findings revealed that the anxiety scores of the prospective teachers regarding the mentioned sub-dimensions were approximately at the same level.

The results of Study 2 revealed a significant difference in all of the sub-dimensions of the anxiety scale according to grade level. It was understood that the scores of the assignment- 
centered anxiety sub-dimension increased as the grade level increased. However, the anxiety scores of all the other dimensions decreased as the grade level increased. The findings revealed that the most significant change happened in the task-centered, self-improvement-centered and student/communication-centered sub-dimensions. In this context, it can be said that the findings of the cross-sectional and longitudinal studies were in conformity. The qualitative study findings also demonstrated that a significant change occurred in the sub-dimensions as the grade level increased, especially in the task-centered and student/communication-centered anxiety subdimensions. The prospective teachers emphasized that the field education and vocational knowledge courses taken in the third and fourth years were influential in reducing and even eliminating their anxiety. The primary courses taken in this regard were education in multigrade classes, classroom management, teaching reading and writing, and teaching math. It is significant that the prospective teachers particularly emphasized these four courses. As a matter of fact, the majority of the assigned teachers worked in village schools consisting of multigrade classrooms. The difficulties of teaching in multigrade classrooms in village schools may cause the candidates to have anxiety in this regard (Atalay \& Yener, 2019; Gürel et al., 2014; Hyry-Beihammer \& Hascher, 2015; Joyce, 2014; Karc1 \& Akar-Vural, 2011; Kucita et al., 2013; Ramrathan \& Ngubane, 2013; Taole \& Mncube, 2012). The reason why classroom management was especially emphasized was that the prospective teachers did not have enough experience in matters such as organizing educational activities, communication with students and creating effective learning environments. Another important remark is the emphasis put on "first reading and writing teaching" and "math teaching". The fact that both courses are taught by primary school teachers for the first time may cause anxiety in prospective teachers. Studies have revealed that teaching these two courses has certain difficulties (Deringöl, 2018; Erbasan \& Erbasan, 2020; Özdemir \& Erdoğan, 2017; Ssentanda $\&$ Asiimwe, 2020). In this case, it can be stated that the field education and vocational knowledge courses had important roles in reducing the anxiety of teacher candidates towards the profession.

The internship practices were considered as the most important factor affecting the change in related sub-dimensions by the prospective teachers. The qualitative findings revealed that monitoring advisors, interacting with students and performing direct practices/experiences were influential in decreasing the anxiety scores. There are various studies that have demonstrated the significant influence of advisors on the training of prospective teachers (Aytaç \& Er, 2018; Caires et al., 2012). The teaching profession is influenced by the master-apprentice relationship as in various other professions (Sarikaya et al., 2017). Moreover, the qualitative findings explaining/ supporting the quantitative findings were related to the change in the task-centered and student/ communication-centered anxiety sub-dimensions. The qualitative findings supported the fact that the direct experiences of the prospective teachers reduced their task-centered anxiety in particular. The prospective teachers emphasized that they had the opportunity to challenge themselves during internship practices in matters such as the manner of teaching, classroom management and method selection. In addition, the findings revealed that being in the same environment as students reduced the anxiety of the prospective teachers with regard to communicating with students. Both the quantitative and qualitative data identified that the assignment-centered anxiety of the prospective teachers increased as the grade level increased. This finding supports the literature (Atmaca, 2013).

\section{Practical Implications and Future Research}

The anxiety levels of prospective primary school teachers were found to decrease systematically from the first year to the fourth. In addition, the number of prospective teachers stating that their anxiety level was high before making a placement selection was found to be quite high. From this point of view, studies can be conducted on the factors affecting the anxiety of prospective teachers when determining their university preferences and the applications performed on career guidance can be examined. It has been revealed that the internship practices decreased the anxiety of the prospective primary school teachers. It may be recommended to increase the internship practice 
hours of teacher candidates. Since the teaching profession is a practice-oriented course in its nature, it can be recommended that all educational institutions that train teachers should consider this situation. A map of the most frequently used keywords in studies conducted on the attitudes and anxieties of prospective primary school teachers towards their profession was created. The researchers are advised to benefit from this information when planning their research and studies.

Disclosure of potential conflicts of interest. The authors declare that they have no conflicts of interest.

Informed consent. Informed consent was obtained for all participants in line with ethical standards for the collection of data with human subjects.

Funding. No funding was received.

Acknowledgement. Researchers thank the prospective teachers who participated in this research. It also thanks the editor of the journal and the referees who will make this research valuable with their contribution.

\section{References}

Abişeva, Ş. (1997). Some factors affecting the choice of profession of education faculty students [Unpublished master's thesis]. Uludağ University, Bursa, Turkey.

Akgün, F., \& Özgür, H. (2014). Examination of the anxiety levels and attitudes of the information technology pre-service teachers towards the teaching profession. Journal of Theory and Practice in Education. 10(5), 1206-1223.

Aksoy, M. E. (2010). Öğretmen adaylarının öğretmenlik mesleğine ilişkin tutumları (Gaziosmanpaşa üniversitesi örneği) [Attitudes of teacher candidates towards teaching profession (Gaziosmanpaşa University example]. The Journal of Social Sciences Research, 2, 199-212.

Andronache, D., Bocoş, M., Bocoş, V., \& Macri, C. (2014). Attitude towards teaching profession. ProcediaSocial and Behavioral Sciences, 142, 628-632.

Aslan, M., \& Sağlam, M. (2018). Evaluation of teaching practice course according to opinions of student teachers. Hacettepe University Journal of Education. 33(1), 144-162. https://doi.org/10.16986/HUJE.2017030313

Atalay, F., \& Yener, Y. (2019). The determination of the anxieties of classroom teacher candidates regarding "Multi-grade class teaching practices". Asian Journal of Instruction, 7(1), 15-31. https:/ / dergipark.org.tr/tr/pub/aji/issue/46556/531979

Atmaca, H. (2013). The professional concerns of teacher candidates who enrolled in English, French and German teaching departments. Turkish Studies - International Periodical for the Languages, Literature and History of Turkish or Turkic, 8(10), 67-76. http://dx.doi.org/10.7827/TurkishStudies.5907

Aytaç, A., \& Er, K. O. (2018). A comparison of teaching practices in pre-service classroom teacher training programs in Turkey and Finland. Journal of Education, Theory and Practical and Research, 4(2), 10-19.

Başbay, M., Ünver, G., \& Bümen, N. T. (2009). A longitudinal study on secondary education teacher candidates' attitudes towards teaching profession. Educational Administration: Theory and Practice, 15(3), 345-366.

Beilock, S. L., Gunderson, E. A., Ramirez, G., \& Levine, S. C. (2010). Female teachers' math anxiety affects girls' math achievement. Proceedings of the National Academy of Sciences, 107(5),1860-1863. https://doi.org/10.1073/pnas.0910967107

Bekdemir, M. (2010). The pre-service teachers' mathematics anxiety related to depth of negative experiences in mathematics classroom while they were students. Educational Studies in Mathematics, 75(3), 311-328.

Bilgin, H., \& Aykac, N. (2016). Pre-Service teachers' teaching-learning conceptions and their attitudes towards teaching profession. Educational Process: International Journal, 5(2), 139-151. http://dx.doi.org/10.12973/edupij.2016.52.5

Bozdam, A. (2008). Öğretmen adaylarının mesleki kaygı düzeylerinin bazı değişkenler açısından incelenmesi [Examination of teacher candidates' professional anxiety levels in terms of some variables] [Master thesis]. Retrieved from Council of Higher Education Thesis Center (Thesis Number: 224882).

Bozdoğan, A. E., Aydın, D., \& Yıldırım, K. (2007). Attitudes of teacher candidates towards teaching profession. Kırşehir Faculty of Education Journal, 8(2), 83-97. 
Cabı, E., \& Yalçınalp, S. (2013). Occupational anxiety scale for prospective teachers: A study on validity and reliability. Hacettepe University Journal of Education, 44, 85-96.

Caires, S., Almeida, L., \& Vieira, D. (2012). Becoming a teacher: Student teachers' experiences and perceptions about teaching practice. European Journal of Teacher Education, 35(2), 163-178. https://doi.org/10.1080/02619768.2011.643395

Conderman, G., Morin, J., \& Stephens, J. T. (2005). Special education student teaching practices. Preventing School Failure: Alternative Education for Children and Youth,49(3), 5-10. https://doi.org/10.3200/PSFL.49.3.5-10

Çapa, Y., \& Çil, N. (2000). Teachers' attitudes towards teaching profession an investigation of different variables. Hacettepe University Journal of Education, 18, 69-73.

Daniels, L. M., Mandzuk, D., Perry, R. P., \& Moore, C. (2011). The effect of teacher candidates' perceptions of their initial teacher education program on teaching anxiety, efficacy, and commitment. Alberta Journal of Educational Research, 57(1), 88-106.

Deringöl, Y. (2018). An examination of the mathematics teaching efficacy and the mathematics teaching anxiety of classroom teacher candidates. Journal of Theoretical Educational Science, 11(2), 261-278. http://dx.doi.org/10.30831/akukeg.364483

Doğan, T., \& Çoban, A. E. (2009). The investigation of the relations between students' attitude toward teaching profession and anxiety level in faculty of education. Education and Science, 153(34), 157-168.

Durdukoca, S. F., \& Atalay, T. D. (2019). Occupational anxiety and self-efficacy levels among prospective teachers. International Journal of Evaluation and Research in Education, 8(1), 173-180. https://doi.org/10.11591/ijere.v8i1.18213

Dursun, S., \& Karagün, E. (2012). Assessment of occupational anxiety levels of preservice teachers: A research on the students in their final year at the school of physical education and sports at Kocaeli University. Kocaeli University Journal of Social Sciences, 24, 93-112.

Ensari, M. Ş., \& Hazal, K. (2017). An investigation on the relationship between demographic variables and the factors affecting occupational choice: An application in Istanbul. Humanitas, 5(10), 409-422. https://doi.org/10.20304/humanitas.358378

Erbasan, Ö., \& Erbasan, Ü. (2020). Difficulties experienced by teachers in primary literacy teaching. Journal of Mother Tongue Education, 8(1), 113-125. https:/ / doi.org/10.16916/ aded.628267

Eret-Orhan, E., \& Ok, A. (2014). Who prefer teacher education programs? Candidates' entry characteristics and attitude towards teaching. Hacettepe University Journal of Education, 29(4), 75-92.

Ergişi, M. B. (2019). Beginning early childhood teachers' reflections on their student teaching experiences. Adiyaman University Journal of Educational Sciences, 9(2), 310-320. https://doi.org/10.17984/adyuebd. 541170

Erkuş, A., Sanlı, N., Bağlı, M. T., \& Güven, K. (2000). Developing an attitude scale toward teaching as a profession. Education and Science, 25(116), 27-33.

Fadlelmula, F. K. (2013). Attitudes of pre-service teachers towards teaching profession. Turkish Journal of Education, 2(4), 55-63. https:// doi.org/10.19128/turje.181070

Ferguson, K., Frost, L., \& Hall, D. (2012). Predicting teacher anxiety, depression, and job satisfaction. Journal of Teaching and Learning, 8(1), 27-42. https://doi.org/10.22329/jtl.v8i1.2896

Field, A. (2013). Discovering statistics using IBM SPSS statistics (4. ed.). Sage.

Fraenkel, J. R., Wallen, N. E., \& Hyun, H. H. (2015). How to design and evaluate research in education (9. ed.). McGraw Hill Education.

Frenzel, A. C., Pekrun, R., Goetz, T., Daniels, L. M., Durksen, T. L., Becker-Kurz, B., \& Klassen, R. M. (2016). Measuring teachers' enjoyment, anger, and anxiety: The Teacher Emotions Scales (TES). Contemporary Educational Psychology, 46, 148-163. https://doi.org/10.1016/ j.cedpsych.2016.05.003

Ghaith, G., \& Shaaban, K. (1999). The relationship between perceptions of teaching concerns, teacher efficacy, and selected teacher characteristics. Teaching and Teacher Education, 15, 487-496. https:// doi.org/10.1016/S0742-051X(99)00009-8

Gresham, G. (2007). A study of mathematics anxiety in pre-service teachers. Early Childhood Education Journal, 35(2), 181-188. https:// doi.org/10.1007/s10643-007-0174-7

Gümrükçü Bilgici, B. (2016). Investigating of the occupational anxieties of preschool teacher candidates [Master thesis]. Retrieved from Council of Higher Education Thesis Center (Thesis Number: 429428).

Güneyli, A., \& Aslan, C. (2009). Evaluation of Turkish prospective teachers' attitudes towards teaching profession (Near East University case). Procedia Social and Behavioral Sciences, 1(1), 313-319. https://doi.org/10.1016/j.sbspro.2009.01.059 
Gürel, N., Çapar, D., \& Kartal, S. (2014). Teacher's perceptions about multi-age classes applications: A $\begin{array}{lllll}\text { qualitative } & \text { research. Journal Human } & \text { Sciences, 11(1), } & \text { 1056-1076. }\end{array}$ https://doi.org/10.14687/IJHS.V1111.2755

Harper, N. W., \& Daane, C. J. (1998). Causes and reduction of math anxiety in preservice elementary teachers. Action in Teacher Education, 19(4), 29-38. https://doi.org/10.1080/01626620.1998.10462889

Henry, P., \& Moscovici, S. (1968). Problèmes de l'analyse de contenu [Problems with content analysis]. Langages, 11, 36-60.

Hollingsworth, H. L., \& Knight-McKenna, M. (2018). "I am now confident": academic service-learning as a context for addressing math anxiety in preservice teachers. Journal of Early Childhood Teacher Education, 39(4), 312-327. https://doi.org/10.1080/10901027.2018. 1514337

Hyry-Beihammer, E. K., \& Hascher, T. (2015). Multi-grade teaching practices in Austrian and Finnish primary schools. International Journal of Educational Research, 74, 104-113. https:// doi.org/10.1016/j.ijer.2015.07.002

Joyce, T. M. (2014). Quality basic education for all: Challenges in multi-grade teaching in rural schools. Mediterranean Journal of Social Sciences, 5(1), 531-536. https://doi.org/10.5901/mjss.2014.v5n1p531

Karc1, C., \& Akar-Vural, R. (2011). Teachers' views with regard to teaching English in multigraded classrooms. Elementary Education Online, 10(2),593-607.

Kesen, İ., \& Polat, M. (2014). Determination of 4th class preservice teachers' attitudes towards the teaching profession in faculty of education: Sample of Muş Alparslan University. Journal of Theory and Practice in Education, 10(2), 556-578.

Kurçiçek, H., \& Yüksel, İ. (2019). The opinions of academicians about school experience and teaching practice Course. Gazi University Journal of Gazi Educational Faculty, 39(3), 1319-1345. https://doi.org/10.17152/gefad.556268

Kucita, P., Kivunja, C., Maxwell, T. W., \& Kuyini, B. (2013). Bhutanese stakeholders' perceptions about multigrade teaching as a strategy for achieving quality universal primary education. International Journal of Educational Development, 33(2), 206-212. https://doi.org/10.1016/j.ijedudev.2012.05.009

Malinsky, M., Ross, A., Pannells, T., \& McJunkin, M. (2006). Math anxiety in pre-service elementary school teachers. Education, 127(2), 274-280.

Miles, M. B., \& Huberman, A. M. (1994). Qualitative data analysis: An expanded sourcebook (2nd ed.). Sage.

Nalçac1, A., \& Sökmen, Y. (2016). The reasons for pre-service teachers to prefer teaching profession and its relationship with their attitudes toward this profession. Journal of Kirsehir Education Faculty, 17(3), 717-720.

Özdemir, C., \& Erdoğan, T. (2017). Determination to self-efficacy beliefs of primary education teacher candidates related to teaching of first reading and writing. Abant Izzet Baysal University Journal of Faculty of Education, 17(1), 314-331. https://doi.org/10.17240/aibuefd.2017.17.28551-304637

Özder, H., Konedralı, G., \& Zeki, C. P. (2010). Examining the attitudes towards the teaching profession and academic achievements of prospective teachers. Educational Administration: Theory and Practice, 2(2), 253275.

Pasaribu, T. A., \& Harendita, M. E. (2018). English language anxiety of pre-service teachers: Causes and coping strategies. LLT Journal: A Journal on Language and Language Teaching, 21(2), 134-147. https://doi.org/10.24071/1lt.2018.210202

Polat, S. (2013). Investigating the attitudes of students from pedagogical formation certificate programs and faculties of education on the prof. E-International Journal of Educational Research, 4(2), 48-60.

Ramrathan, L., \& Ngubane, T. I. (2013). Instructional leadership in multi-grade classrooms: What can monograde teachers learn from their resilience? Education as Change, 17(1), 93-105. https://doi.org/10.1080/16823206.2014.865995

Saka, M. (2019). Evulations of science teachers regarding the classes of school experience and teaching practices. Elementary Education Online, 18(1), 127-148.

Sarikaya, İ., Samanc1, O., \& Y1lar, Ö. (2017). Assessment of candidate teacher training process in the scope of candidate and mentor primary school teachers' opinions: A mixed method study. Gazi University Journal of Gazi Educational Faculty (GUJGEF), 37(3), 939-989.

Serï, M., Güneş, A., \& Değirmenci, H. (2015). The relationship between the attitudes towards teaching profession and the anxiety level of prospective primary school teachers. Cumhuriyet International Journal of Education, 4(1), 21-34. https:// doi.org/10.30703/cije.321360 
Silvernail, D. L., \& Costello, M. H. (1983). The impact of student teaching and internship programs on preservice teachers' pupil control perspectives, anxiety levels, and teaching concerns. Journal of Teacher Education, 34(4), 32-36. https:// doi.org/10.1177/002248718303400409

Spielberg, C. D., \& Vagg, P. R. (1995). Test anxiety: Theory, assessment and treatment. Taylor \& Francis.

Ssentanda, M., \& Asiimwe, A. (2020). Challenges to the acquisition of literacy in rural primary schools in Northern Uganda. Language Matters, 51(1), 38-62. https://doi.org/10.1080/10228195.2020.1717587

Taole, M., \& Mncube, V. S. (2012). Multi-grade teaching and quality of education in South African rural schools: Educators' experiences. Studies of Tribes and Tribals, 10(2), 151-162. https://doi.org/10.1080/0972639X.2012.11886653

Taşdemir, C. (2014). To investigate the elementary mathematics teacher candidates' attitudes to the teaching profession. Journal of Computer and Education Research, 2(3), 91-113.

Taşğın, Ö. (2006). Observation of concern levels teacher candidates, who enrolled physical education and sports college, according to some variables. Kastamonu Education Journal, 14(2), 679-686.

Tezci, E., \& Terzi, A. R. (2010). An examination on the attitudes towards teaching profession of the students of secondary school branch teacher training programs. Education Sciences, 5(2), 367-388.

Tok, T. N. (2012). Teacher candidates' attitudes towards the teaching profession in Turkey. Alberta Journal of Educational Research, 58(3), 381-403.

Tooke, D. J., \& Lindstrom, L. C. (1998). Effectiveness of a mathematics methods course in reducing math anxiety of preservice elementary teachers. School Science and Mathematics, 98(3), 136-139. https://doi.org/10.1111/j.1949-8594.1998.tb17406.x

Uyanık, G. (2017). Examination of the elementary teacher candidates attitudes towards teaching profession according to various variables: A longitudinal research. International Journal of Turkish Education Sciences, $5(8), 185-195$.

Van der Sandt, S., \& O'Brien, S. (2017). Impact of instructor teaching style and content course on mathematics anxiety of preservice teachers. Journal of Technology Education,29(1), 95-111. https://doi.org/10.21061/jte.v29i1.a.5

Yıldırım, A. (2011). Sinı öğretmeni adaylarının meslekî öz-yeterlik algılar ile meslekî kaygı düzeyleri arasındaki ilişkinin incelenmesi [Examining the relationship between the professional self-efficacy perceptions of primary school teacher candidates and their occupational anxiety levels] [Master thesis]. Retrieved from Council of Higher Education Thesis Center (Thesis Number: 298589).

Zeidner, M. (2007). Test anxiety in educational contexts: Concepts, findings, and future directions. In P. Schutz \& R. Pekrun (Eds.), Emotion in education (pp. 165-184). Academic Press. 